\title{
PENGOMPOSAN SAMPAH ORGANIK (KUBIS DAN KULIT PISANG) DENGAN MENGGUNAKAN EM4
}

\author{
Nunik Ekawandani ${ }^{1}$, Arini Anzi Kusuma2) \\ 1),2)Teknik Kimia, Politeknik TEDC Bandung \\ Email : nunik.ekawandani@gmail.com ${ }^{1}$, arin.anzi21@gmail.com²)
}

\begin{abstract}
Abstrak
Sampah organik yang ada di Indonesia berasal dari pasar, rumah tangga, restoran dan hotel. Sampah organik merupakan sampah padat yang mudah membusuk dan menimbulkan bau yang sangat menyengat. Keberadaan sampah ini sangat mengganggu kebersihan dan kesehatan lingkungan. Keberadaan sampah ini tidak terlepas dari pola kecenderungan konsumsi masyarakat itu sendiri. Maka diperlukan pengelolaan sampah organik yang tepat. Dalam penelitian ini akan memanfaatkan sampah organik dari kubis dan kulit pisang, menjadi kompos. Pengomposan biasanya menggunakan cara konvensional, dimana dengan cara ini membutuhkan waktu cukup lama. Pengomposan dengan bantuan EM4 (Effective Microorganism) dapat mempercepat dalam pembuatan kompos dibandingkan dengan cara konvensional. Hasil dari penelitian ini menunjukan bahwa dalam waktu 20 hari kompos sudah dapat digunakan. Adapun kandungan kompos yang dihasilkan menunjukan kadar rasio $\mathrm{C} / \mathrm{N}$ sebesar 18 , kalium $2,11 \%$ dan fosfor $0,26 \%$ dengan sifat fisik kompos berwarna coklat kehitaman, berbau dan bertekstur seperti tanah dengan kadar air $13,98 \%$, suhu $27^{\circ} \mathrm{C}$ dan $\mathrm{pH} 7$.
\end{abstract}

Kata kunci: sampah organik, kubis, kulit pisang, kompos, EM4

\begin{abstract}
The organic waste in Indonesia comes from markets, households, restaurants, and hotels. Organic waste is solid waste that is easy to decompose and come a very stinging smell. The waste pollute cleanliness and environmental health. The waste occurred from the consume pattern of society itself. There for the right waste management is required. The study will utilize organic waste from cabbage and banana peel in to compost. Composting usually uses the conventional method which is it a long time. Composting using EM4 can accelerate in composting process. The results of the study indicate within 20 days of compost can be used. The the compost content produced showed the ratio of $\mathrm{C} / \mathrm{N}$ ratio of $18,2,11 \%$ of potassium and $0,26 \%$ of phosphor with physical properties of black brown, smelly and textured like dirt wih air content of 13,98\% temperature $27^{\circ} \mathrm{C}$ and $\mathrm{pH} 7$.
\end{abstract}

Keywords: organic waste, cabbage, banana peel, EM4

\section{Pendahuluan}

Sampah menjadi masalah yang sangat pelik terutama di Indonesia, dimana sampah belum dikelola belum baik, ditambah lagi dengan pertumbuhan penduduk Indonesia yang sangat pesat terutama di perkotaan mengakibatkan peningkatan jumlah sampah. Selama ini sampah hanya dipiindahkan dari sumber sampah ke tempat yang lebih luas yaitu ke tempat pembuangan akhir (TPA) dengan sistem open dumping di landfill. Ditambah lagi dengan kesadaran masyarakat akan pentingnya membuang sampah terutama sampah organik. Jumlah komposisi dan karakteristik sampah tidak terlepas dari pola kecenderungan konsumsi masyarakat itu sendiri (Damanhuri, 1:2016). Sampah organik adalah jenis sampah yang paling banyak di buang oleh masyarakat, dimana sampah organik ini memiliki kandungan air yang tinggi sehingga cepat mengalami pembusukan. Ketika membusuk sampah organik menimbulkan bau busuk yang dapat penyebabkan pencemaran lingkungan dan menjadi sumber penyakit.

Dengan keadaan seperti ini perlu dilakukan untuk mengelola sampah dengan lebih baik, agar tidak terjadi penumpukan yang dapat menyebabkan kerusakkan lingkungan yaitu dari sisi kesehatan. Sebagai salah satu cara pemanfaatan sampah ini adalah dengan mengelolanya menjadi pupuk kompos yang bisa di manfaatkan untuk para petani, sebagai pupuk alami yang bisa menjadi pilihan sebagai pupuk ramah lingkungan.

Pengelolaan sampah dengan menjadikan pupuk kompos bisa dilakukan dengan cara konvensional dan penggunaan Effective Microorganism (EM4). Pengomposan menurut Djuarnani dkk (2005:6) merupakan proses dekomposisi terkendali secara biologis terhadap sampah padat organik dalam kondisi aerobik (terdapat oksigen) atau anaerobik (tanpa oksigen). Bahan organik akan diubah hingga menyerupai tanah. Kondisi terkendali tersebut 
mencakup rasio karbon dan nitrogen $(\mathrm{C} / \mathrm{N})$, kelembapan, $\mathrm{pH}$ dan kebutuhan oksigen.

\section{LANDASAN TEORI}

Menurut Undang-undang No. 18 tahun 2008, sampah adalah sebagai sisa kegiatan sehari-hari manusia dan/atau dari proses alam yang berbentuk padat., berdasarkan karakteristik sampah makanan termasuk kedalam garbage, misalnya sampah yang berasal dari rumah makan, rumah tangga, pasar tradisional dll (Hodges, 1976: 280-281). Damanhuri, 2016: 29,sampah pasar tradisional yang menghasilkan sisa sayur, buah dan makanan yang mudah membusuk. Sampah ini umumnya memberikan citra yang kumuh pada sebuah kota bila tidak ditangani secara baik, karena tumpukan sampah yang banyak dan menyebarkan bau tersebut berada di keramaian kota, kadang menyatu dengan daerah komersial.

\section{Pupuk organik}

Pupuk organik merupakan hasil akhir dari peruraian bagian-bagian atau sisa-sisa (serasah) tanaman dan binatang. Pupuk organik bermanfaat untuk menggemburkan lapisan permukaan tanah (top soil) meningkatkan populasi jasad renik, mempertinggi daya serap dan daya simpan air sehingga dapat meningkatkan kesuburan tanah.

Berdasarkan jenisnya pupuk organik terdiri dari :

a. Pupuk kandang, pupuk yang terbuat dari kotoran hewan

b. Pupuk hijau, terbuat dari tanaman atau bagian tanaman yang masih hijau yang di benamkan ke dalam tanah dengan maksud agar dapat meningkatkan ketersediaan bahan organik dan unsur hara bagi pertumbuhan dan perkembangan tanaman. Jenis tanaman yang cocok adalah dari family leguminosa seperti Crotarea juncea (orok-orok)

c. Kompos, merupakan sisa bahan organik yang berasal dari tanaman, hewan dan sampah organik yang telah mengalami proses dekomposisi atau fermentasi. Bahan mentahnya bisa berupa sisa tanaman, sampah dapur dan sebagainya. Bisa menjadi kompos akibat prose pelapukan dan penguraian.

d. Pupuk organik lainnya

- Night soil, pupuk yang terbuat dari kotoran manusia (cair dan padat)

- Pupuk unggas, pupuk yang terbuat dari kotoran unggas

- Pupuk bungkil, pupuk yang berasal dari sisa-sisa pembuatan minyak, seperti bungkil kacang, wijen, biji kapuk.

\section{Kompos}

Habibi (2008:10) kompos merupakan istilah untuk pupuk organik buatan manusia yang dibuat dari proses pembusukan sisa-sisa bahan organik.
Proses pengomposan dapat berlangsung secara aerobik dan anaerobik yang saling menunjang pada kondisi lingkungan tertentu. Secara keseluruhan proses ini disebut dekomposisi atau penguraian.

Kompos bermanfaat untuk :

a. Memperbaiki struktur tanah menjadi lebih gembur

b. Memperkuat daya ikat agregat tanah berpasir

c. Meningkatkan daya tahan dan daya serap air

d. Memperbaiki drainase dan pori-pori dalam tanah

e. Menambah dan mengaktifkan unsur hara

f. Meningkatkan daya ikat tanah terhadap unsur hara

g. Membantu dekomposisi bahan mineral

h. Menyediakan bahan makanan bagi mikroorganisme yang menguntungkan pertumbuhan tanaman.

Keunggulan kompos dibandingkan dengan pupuk anorganik menurut Djuarnani dkk (2005:10-11) yaitu,

a. Sifat Kompos

1. Mengandung unsur hara makro dan mikro yang lengkap walaupun dalam jumlah yang sedikit.

2. Dapat memperbaiki struktur tanah dengan cara sebagai berikut :

a) Menggemburkan dan meningkatkan ketersediaan bahan organik didalam tanah.

b) Meningkatkan daya serap tanah terhadap air dan zat hara.

c) Memperbaiki kehidupan mikroorganisme didalam tanah dengan cara menyediakan bahan makanan bagi mikroorganisme tersebut.

d) Memperbesar daya ikat tanah berpasir, sehingga tidak mudah terpencar.

e) Memperbaiki drainase dan tata udara di dalam tanah.

f) Membantu proses pelapukan bahan mineral.

g) Melindungi tanah terhadap kerusakan yang disebabkan erosi.

h) Meningkatkan kapasitas tukar kation (KTK).

3. Beberapa tanaman yang menggunakan kompos lebih tahan terhadap serangan penyakit.

4. Menurunkan aktivitas mikroorganisme tanah yang merugikan.

b. Sifat Pupuk Anorganik

1. Hanya mengandung satu atau beberapa unsur hara, tetapi dalam jumlah banyak.

2. Tidak dapat memperbaiki struktur tanah, tetapi justru penggunaan dalam jangka waktu panjang dapat membuat tanah menjadi keras.

3. Sering membuat tanaman manja sehingga rentan terhadap penyakit. 
Tabel 1. Standar kualitas kompos

\begin{tabular}{|c|c|c|c|c|}
\hline No. & Parameter & Satuan & Minimum & Maksimum \\
\hline 1. & Kadar air & $\%$ & - & 50 \\
\hline 2. & Temperatur & ${ }^{\circ} \mathrm{C}$ & & $\begin{array}{l}\text { Suhu ai } \\
\text { tanah }\end{array}$ \\
\hline 3. & Warna & & & Kehitaman \\
\hline 4. & Bau & & & $\begin{array}{l}\text { Berbau } \\
\text { tanah }\end{array}$ \\
\hline 5. & Ukuran partikel & $\mathrm{mm}$ & 0,55 & 25 \\
\hline 6. & Kemampuan ikat air & $\%$ & 58 & 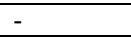 \\
\hline 7. & $\mathrm{pH}$ & & 6,80 & 7,49 \\
\hline 8. & Bahan asing & $\%$ & $*$ & 1,5 \\
\hline \multicolumn{5}{|c|}{ Unsur makro } \\
\hline 9. & Bahan organik & $\%$ & 27 & 58 \\
\hline 10. & Nitrogen & $\%$ & 0,40 & - \\
\hline 11. & Karbon & $\%$ & 9,80 & 32 \\
\hline 12. & Phosfor $\left(\mathrm{P}_{2} \mathrm{O}_{5}\right)$ & $\%$ & 0,10 & - \\
\hline 13. & C/N-rasio & & 10 & 20 \\
\hline 14. & Kalium $\left(\mathrm{K}_{2} \mathrm{O}\right)$ & $\%$ & 0,20 & * \\
\hline \multicolumn{5}{|c|}{ Unsur mikro } \\
\hline 15. & Arsen & $\mathrm{mg} / \mathrm{kg}$ & * & 13 \\
\hline 16. & Kadnium (CD) & $\mathrm{mg} / \mathrm{kg}$ & $*$ & 3 \\
\hline 17. & Kobal $(\mathrm{CO})$ & $\mathrm{mg} / \mathrm{kg}$ & $*$ & 34 \\
\hline 18. & Kromium $(\mathrm{Cr})$ & $\mathrm{mg} / \mathrm{kg}$ & * & 210 \\
\hline 19. & Tembaga $(\mathrm{Cu})$ & $\mathrm{mg} / \mathrm{kg}$ & $*$ & 100 \\
\hline 20. & Merkuri $(\mathrm{Hg})$ & $\mathrm{mg} / \mathrm{kg}$ & $*$ & 0,8 \\
\hline 21. & Nikel (Ni) & $\mathrm{mg} / \mathrm{kg}$ & * & 62 \\
\hline 22, & Timbal $(\mathrm{Pb})$ & $\mathrm{mg} / \mathrm{kg}$ & * & 150 \\
\hline 23. & Selamium (Se) & $\mathrm{mg} / \mathrm{kg}$ & $*$ & 2 \\
\hline 24. & Seng (Zn) & $\mathrm{mg} / \mathrm{kg}$ & $*$ & 500 \\
\hline \multicolumn{5}{|c|}{ Unsur lain } \\
\hline 25. & Kalsium & $\%$ & * & 25,50 \\
\hline 26. & Magnesium (Mg) & $\%$ & $*$ & 0,60 \\
\hline 27. & Besi $(\mathrm{Fe})$ & $\%$ & $*$ & 2,00 \\
\hline 28. & Alumunium (Al) & $\%$ & $*$ & 2,20 \\
\hline 29. & Mangan (Mn) & $\%$ & $*$ & 2,10 \\
\hline \multicolumn{5}{|c|}{ Bakteri } \\
\hline 30. & Fecal coli & MPN/g & & 1000 \\
\hline 31. & Salmonella sp & $\mathrm{MPN} / 4 \mathrm{~g}$ & & 3 \\
\hline
\end{tabular}

Sumber : SNI 19-7030-2004

\section{METODE PENELITIAN}

Penelitian yang dilakukan adalah penelitian deskriptif, dimana menggambarkan kondisi penelitian apa adanya. Dengan kondisi yang sebisa mungkin sesuai lingkungan aslinya.

\section{PEMBAHASAN}

Analisis kompos padat dilakukan pada awal pengomposan (hari ke-0) dan pada akhir pengomposan (hari ke-20). Pada awal pengomposan analisis yang dilakukan adalah analisis kadar C-organik dan N-organik. Pada akhir pengomposan analisis yang dilakukan adalah analisis kadar air, C-organik, N-organik, kalium dan fosfor.

Analisis kompos padat dilakukan pada awal pengomposan (hari ke-0) dan pada akhir pengomposan (hari ke-20). Pada awal pengomposan analisis yang dilakukan adalah analisis kadar C-organik dan N-organik. Pada akhir pengomposan analisis yang dilakukan adalah analisis kadar air, C-organik, N-organik, kalium dan fosfor.

Penentuan kadar air kompos dilakukan dengan melakukan penimbangan awal sampel dan penimbangan akhir sampel setelah dikeluarkan dari oven seperti yang terdapat pada tabel 2 menunjukkan data hasil penimbangan sampel kompos dalam menentukan kadar air.

Tabel 2. Hasil penimbangan penentuan kadar air

\begin{tabular}{|c|c|c|}
\hline Sampel & Berat Awal (g) & Berat Akhir (g) \\
\hline I & 10,1712 & 9,4277 \\
\hline II & 9,9552 & 9,2138 \\
\hline
\end{tabular}

Pada analisis penentuan kadar $\mathrm{N}$-organik kompos padat, setelah sampel didestilasi kemudian sampel dititrasi menggunakan $\mathrm{H}_{2} \mathrm{SO}_{4}$, diperoleh volume $\mathrm{H}_{2} \mathrm{SO}_{4}$ seperti ditunjukkan oleh tabel 3.

Tabel 3. Volume $\mathrm{H}_{2} \mathrm{SO}_{4}$ yang digunakan dalam penentuan kadar $\mathrm{N}$-organik

\begin{tabular}{|l|l|l|l|l|}
\hline No & $\begin{array}{c}\text { Waktu } \\
\text { Analisis }\end{array}$ & Sampel & $\begin{array}{c}\text { Berat } \\
\text { Sampel } \\
(\mathbf{g})\end{array}$ & $\begin{array}{c}\text { Volume } \\
\mathbf{H}_{\mathbf{2}} \mathbf{S O}_{\mathbf{4}} \\
(\mathbf{m l})\end{array}$ \\
\hline 1. & \multirow{2}{*}{ Hari ke-0 } & I & 0,2501 & 6,50 \\
\cline { 3 - 5 } & & II & 0,2503 & 6,80 \\
\hline 3. & \multirow{2}{*}{ Hari ke-20 } & I & 0,2504 & 5,75 \\
\cline { 3 - 5 } & II & 0,2506 & 6,35 \\
\hline 4. & & \multicolumn{2}{|l}{} \\
\hline
\end{tabular}

Pada analisis penentuan kadar C-organik, kalsium dan fosfor dalam kompos padat, sampel yang sudah diberi perlakuan awal kemudian diukur menggunakan alat pengukuran untuk mengetahui nilai absorbansinya seperti pada tabel 4., menunjukkan data ppm kurva hasil pengukuran.

Tabel 4. Data ppm kurva hasil pengukuran

\begin{tabular}{|c|c|c|c|c|c|}
\hline No & Parameter & $\begin{array}{l}\text { Waktu } \\
\text { Analisis }\end{array}$ & Sampel & $\begin{array}{l}\text { Berat } \\
\text { Sampel } \\
\text { (g) }\end{array}$ & $\begin{array}{l}\text { ppm } \\
\text { Kurva }\end{array}$ \\
\hline 1. & \multirow{4}{*}{ C-organik } & \multirow{2}{*}{ Hari ke-0 } & I & 0,0502 & 265 \\
\hline 2. & & & II & 0,0504 & 255 \\
\hline 3. & & \multirow{2}{*}{ Hari ke-20 } & I & 0,0502 & 146 \\
\hline 4. & & & II & 0,0500 & 166 \\
\hline 5. & \multirow{2}{*}{ Kalium } & \multirow{2}{*}{ Hari ke-20 } & I & 0,5001 & 8,661 \\
\hline 6. & & & II & 0,5004 & 8,856 \\
\hline 7. & \multirow{2}{*}{ Fosfor } & \multirow{2}{*}{ Hari ke-20 } & I & 0,5001 & 1,26 \\
\hline 8. & & & II & 0,5004 & 1,04 \\
\hline
\end{tabular}

Pada penelitian pemanfaatan sampah kubis dan kulit pisang menjadi kompos padat menggunakan aktivator EM4 kondisi pengomposan yang digunakan adalah pengomposan secara anaerob. Proses pengomposan diawali dengan mengumpulkan bahan organik berupa sampah kubis dan kulit pisang sebagai bahan baku pengomposan yang kemudian ditambah larutan EM4 sebagai aktivator untuk mempercepat proses pengomposan. Selama proses pengomposan, pembolak-balikan kompos dilakukan 2 hari sekali dan sifat fisik dari kompos diamati, adapun sifat fisik yang diamati adalah $\mathrm{pH}$, suhu, tekstur, bau dan warna kompos. Hasil pengomposan berupa kompos padat yang sudah matang dianalisis kadar air, C-organik, Norganik, rasio $\mathrm{C} / \mathrm{N}$, kalium, fosfor dan sifat fisik 
lainnya kemudian disesuaikan dengan standar SNI.

\section{Sifat Fisik Selama Pengomposan Suhu Pengomposan}

Suhu selama pengomposan terus mengalami perubahan seperti yang ditunjukkan oleh gambar 1 yaitu suhu pada awal pengomposan adalah $28^{\circ} \mathrm{C}$ kemudian suhu mengalami penurunan dan kenaikan sehingga pada hari ke-20 suhu kompos adalah $27^{\circ} \mathrm{C}$.

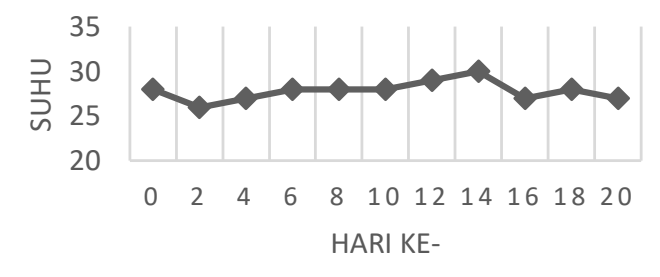

Gambar 1. Suhu pengomposan

Suhu merupakan salah satu faktor yang mempengaruhi laju pengomposan, karena mikroorganisme perombak masing-masing memiliki suhu optimum dalam aktivitasnya seperti menurut Djuarnani dkk (2005:30) bahwa mikroorganisme yang hidup pada temperatur rendah $\left(10{ }^{\circ} \mathrm{C}-45^{\circ} \mathrm{C}\right)$ adalah mikroorganisme mesofilik dan mikroorganisme yang hidup pada temperatur tinggi $\left(45^{\circ} \mathrm{C}-65^{\circ} \mathrm{C}\right)$ adalah mikroorganisme termofilik. Suhu pengomposan yang paling baik adalah $10^{\circ} \mathrm{C}-45^{\circ} \mathrm{C}$. Pada penelitian ini dilakukan proses pengomposan secara anaerob, proses anaerob ini merupakan proses yang dingin sehingga dibutuhkan tambahan suhu dari luar sebesar $30^{\circ} \mathrm{C}$ untuk meningkatkan suhu pengomposan. Namun, pengomposan pada peneitian ini dilakukan didalam laboratorium dengan suhu ruang $27^{\circ} \mathrm{C}$. $\mathrm{Hal}$ ini menyebabkan suhu selama proses proses pengomposan menjadi relatif rendah yaitu dengan kisaran $26^{\circ} \mathrm{C}-30^{\circ} \mathrm{C}$.

\section{pH Pengomposan}

Perubahan $\mathrm{pH}$ selama pengomposan seperti pada gambar $\mathbf{2}$ menunjukkan bahwa selama proses pengomposan $\mathrm{pH}$ mengalami kenaikan yang signifikan yaitu $\mathrm{pH}$ pada hari ke-0 sampai hari ke-12 adalah 5 (asam), pada hari ke-14 sampai hari ke-16 pH meningkat menjadi 6 dan pada hari ke-18 sampai hari ke-20 pH meningkat lagi menjadi 7 (netral).

Nilai pH selama masa pengomposan sangat mempengaruhi terhadap pertumbuhan mikrooorganisme perombak. Nilai pH yang terlalu tinggi akan membuat unsur nitrogen dalam bahan kompos berubah menjadi ammonia $\left(\mathrm{NH}_{3}\right)$.
Sebaliknya, nilai pH yang terlalu rendah akan menyebabkan sebagian mikroorganisme perombak mati sehingga dapat mengganggu proses pengomposan. Selama proses pengomposan, $\mathrm{pH}$ kompos mengalami kenaikan karena terjadinya penguraian protein dalam bahan organik dan pelepasan ammonia.

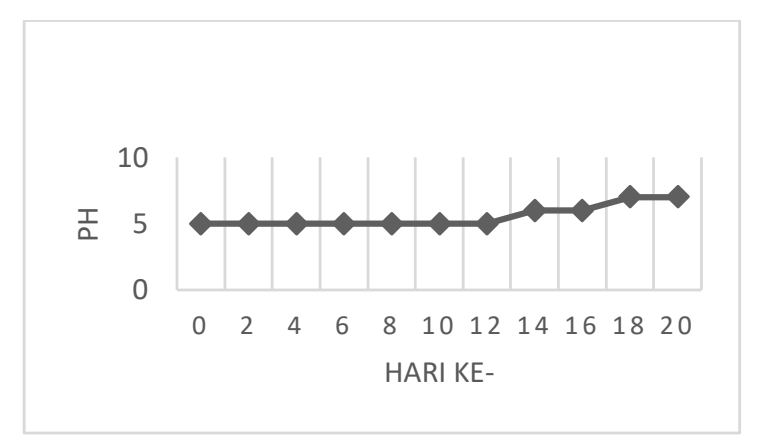

Gambar 2. pH Pengomposan

Sifat Fisik Lainnya

Sifat fisik lainnya yang diperhatikan dalam penelitian ini adalah warna, tekstur dan bau dari kompos. Selama pengomposan terjadi perubahan fisik pada kompos seperti yang ditunjukkan oleh gambar 3 yang menunjukkan perubahan fisik pada kompos.

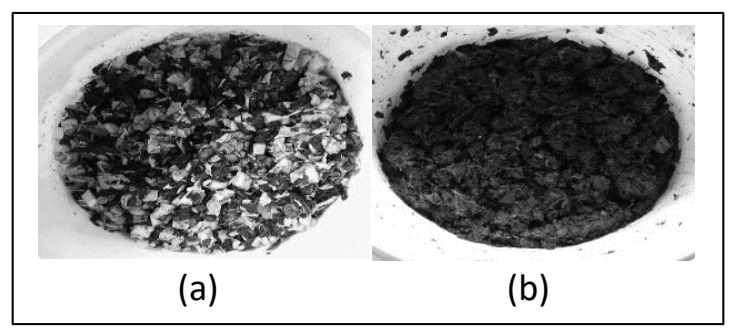

Gambar 3. Fisik kompos pada awal dan akhir pengomposan

(a) Kompos hari ke-0

(b) Kompos hari ke-20

Pada awal pengomposan, warna kompos masih berwarna sayuran asli dengan bau sayuran segar dan teksturnya masih utuh dengan ukuran kurang lebih $1 \mathrm{~cm}$. Selama proses pengomposan, terjadi perubahan terhadap sifat fisik kompos yaitu warna kompos berubah menjadi kecoklatan dengan bau menyengat dan tekstur mulai hancur. Kemudian pada hari ke-20 kompos menunjukan ciri-ciri kematangan secara fisik, yaitu kompos berwarna coklat kehitaman dengan bau dan tekstur seperti tanah.

\section{Hasil Analisis Kompos Padat}

Hasil dari analisa laboratorium kompos padat dari sampah kubis dan kulit pisang didapat data seperti yang terdapat pada tabel $\mathbf{5}$ yang terdiri dari kadar air, temperatur, warna, bau, pH, Corganik, $\mathrm{N}$-organik, $\mathrm{C} / \mathrm{N}$ rasio, kadar kalium dan fosfor. 
Tabel 5. Hasil pengujian kualitas kompos padat

\begin{tabular}{|c|c|c|c|c|c|}
\hline \multirow{2}{*}{ No } & \multirow{2}{*}{ Parameter } & \multirow{2}{*}{ Satuan } & \multicolumn{2}{|c|}{$\begin{array}{c}\text { SNI Kualitas } \\
\text { Kompos }\end{array}$} & \multirow{2}{*}{$\begin{array}{c}\text { Hasil } \\
\text { Pengujian }\end{array}$} \\
\hline & & & Min & Maks & \\
\hline 1. & Kadar Air & $\%$ & - & 50 & 13,98 \\
\hline 2. & Temperatur & ${ }^{\circ} \mathrm{C}$ & - & $\begin{array}{l}\text { Suhu } \\
\text { air } \\
\text { tanah }\end{array}$ & 27 \\
\hline 3. & Warna & - & - & $\begin{array}{l}\text { Kehitam } \\
\text { an }\end{array}$ & $\begin{array}{l}\text { Coklat } \\
\text { kehitama } \\
\mathrm{n}\end{array}$ \\
\hline 4. & Bau & - & - & $\begin{array}{l}\text { Berbau } \\
\text { tanah }\end{array}$ & $\begin{array}{l}\text { Berbau } \\
\text { tanah }\end{array}$ \\
\hline 5. & $\mathrm{pH}$ & - & 6,80 & 7,49 & 7 \\
\hline 6. & C-Organik & \multirow{2}{*}{$\%$} & 9,80 & 32 & 31,11 \\
\hline 7. & $\mathrm{~N}$ & & 0,40 & - & 1,75 \\
\hline 8. & $\mathrm{C} / \mathrm{N}$ rasio & - & 10 & 20 & 18 \\
\hline 9. & Kadar $\mathrm{P}_{2} \mathrm{O}_{5}$ & \multirow{2}{*}{$\%$} & 0,10 & - & 0,26 \\
\hline 10. & Kadar $\mathrm{K}_{2} \mathrm{O}$ & & 0,20 & $*$ & 2,11 \\
\hline
\end{tabular}

Berdasarkan data yang terdapat pada tabel 5 diatas menunjukkan bahwa kualitas kompos padat dari sampah kubis dan kulit pisang secara umum sudah memenuhi standar kualitas kompos SNI 19-7030-2004.

\section{Rasio C/N}

Rasio $\mathrm{C} / \mathrm{N}$ pada saat pengomposan mengalami penurunan seperti yang ditunjukan oleh tabel 6 yaitu rasio $\mathrm{C} / \mathrm{N}$ pada awal masa pengomposan (hari ke-0) adalah 27 dan akhir masa pengomposan (hari ke-20) adalah 18.

Tabel 6. Rasio C/N pada awal dan akhir

\begin{tabular}{|l|l|l|l|l|}
\multicolumn{5}{|c|}{ pengomposan } \\
\hline No & Parameter & Satuan & \multicolumn{1}{|c|}{$\begin{array}{c}\text { Hari } \\
\text { ke-0 }\end{array}$} & $\begin{array}{c}\text { Hari } \\
\text { ke-20 }\end{array}$ \\
\hline 1. & C-organik & \multirow{2}{*}{$\%$} & 51,70 & 31,11 \\
\hline 2. & N-organik & & 1,93 & 1,75 \\
\hline 3. & C/N rasio & - & 27 & 18 \\
\hline
\end{tabular}

Terjadinya penurunan rasio $\mathrm{C} / \mathrm{N}$ seperti pada tabel 6 ini sesuai dengan prinsip pengomposan menurut Djuarnani dkk (2005:6) yaitu menurunkan nilai rasio $\mathrm{C} / \mathrm{N}$ bahan organik menjadi sama dengan nilai rasio $\mathrm{C} / \mathrm{N}$ tanah. Dengan rasio $\mathrm{C} / \mathrm{N}$ yang sama dengan tanah akan memudahkan penyerapan kandungan kompos kedalam tanah. Kadar rasio $\mathrm{C} / \mathrm{N}$ pada awal masa pengomposan sangat mempengaruhi terhadap laju proses pengomposan. Rasio $\mathrm{C} / \mathrm{N}$ awal yang rendah akan membuat proses pembusukan menjadi lebih cepat sedangkan rasio $\mathrm{C} / \mathrm{N}$ awal yang tinggi karena memiliki kadar karbon yang tinggi akan membuat proses pembusukan menjadi lebih lama. Dalam proses pengomposan, karbon berperan sebagai sumber energi bagi mikroorganisme dan nitrogen berperan dalam pembentukan mikroorganisme. Selama proses pengomposan $\mathrm{CO}_{2}$ akan mengalami penguapan sehingga kadar karbon (C) akan menurun dan kadar nitrogen $(\mathrm{N})$ akan meningkat. Hal ini yang membuat rasio $\mathrm{C} / \mathrm{N}$ kompos menjadi turun. Namun, pada penelitian ini kadar $\mathrm{N}$ menurun. Hal ini disebabkan karena pori-pori tumpukan kompos yang besar sehingga menyebabkan nitrogen yang terbentuk dari hasil dekomposisi terlepas ke udara.

\section{Kalium}

Kadar kalium yang terdapat dalam kompos padat dari sampah kubis dan kulit pisang seperti pada tabel 5 adalah 2,11 \%. Pada dasarnya dalam bahan organik sudah terdapat kandungan kalium, namun kalium tersebut masih dalam bentuk organik kompleks sehingga tidak dapat diserap langsung olah tanaman. Dengan terjadinya proses dekomposisi, bahan organik kompleks tersebut akan terurai menjadi bahan organik yang lebih sederhana sehingga menghasilkan unsur kalium yang dapat diserap oleh tanaman. Bagi tamanam, kalium memiliki peranan penting dalam proses fotosintesis dalam pembentukan protein dan selulosa yang berfungsi untuk memperkuat batang tanaman. Semakin tinggi kadar kalium dalam kompos maka semakin baik bagi pertumbuhan batang tanaman.

\section{Fosfor}

Hasil analisis kadar fosfor total dalam kompos pada tabel 5 menunjukan kadar fosfor yang terdapat dalam kompos adalah 0,26\% dengan batas minimum SNI kompos 0,10 \% dan tidak ada batasan maksimum. Dalam pembuntukan fosfor selama pengomposan, mikroorganisme memiliki peran yang sangat penting. Selama proses dekomposisi terjadi, senyawa $\mathrm{P}$ organik yang terdapat dalam bahan organik diubah dan dimineralisasikan menjadi senyawa organik yang dapat diserap oleh tanaman. Bagi tumbuhan, fosfor memiliki peranan penting dalam proses fotosintesis dan fisiologi kimiawi tanaman dalam pembelahan sel dan pengembangan jaringan tanaman. Selain itu, fosfor juga berperan dalam meningkatkan unsur hara tanah dan kesuburan tanah.

\section{KESIMPULAN DAN SARAN}

\section{Kesimpulan}

Secara keseluruhan hasil dari penelitian pengomposan sampah organik berupa kubis dan kulit pisang dengan campuran EM4 memenuhi standar SNI 19-7030-2004. Sehingga kompos ini sudah dapat digunakan sebagai pupuk organik.

\section{Saran}

Melakukan pengomposan dengan bahan baku yang lebih variatif lagi, misalkan sampah organik dari rumah tangga yang komposisinya lebih kompleks lagi. Sehingga dapat mengurangi penumpukan sampah di lingkungan sekitar. 


\section{DAFTAR PUSTAKA}

Damanhuri, Enri.Padmi, Tri.(2016).Pengelolaan Sampah Terpadu.Bandung:ITB

Djuarnani, N., Kristian dan Setiawan, B.S. (2005). Cara Cepat Membuat Kompos. Cetakan 1. Jakarta : AgroMedia Pustaka

Habibi, Lafran (2008). Pembuatan Pupuk Kompos dari Limbah Rumah Tangga. Cetakan 1. Bandung : Penerbit Titian Ilmu
Hodges,

Laurent.(1976). Environmental Pollution. $2^{\text {nd }}$ edition.holt McDougal

SNI 19-7030-2004. Spesifikasi kompos dari sampah organik domestik. http://inswa.or.id/wpcontent/uploads/2012/07/Spesifikasikompos-SNI.pdf. Diakses pada 27 Desember 2017 